\title{
As parcerias público-privadas e terceirizações na área da saúde no Brasil: um balanço crítico
}

\author{
Fábio CEGATTI ${ }^{(1)}$ \\ Áquilas Nogueira MENDES ${ }^{(1)}$ \\ (1)Faculdade de Saúde Pública, Universidade de São Paulo - USP, São Paulo, SP, Brasil.
}

Recebido: 28 jan 2019 Aceito: 10 fev 2019

Autor de correspondência: fabiocegatti@yahoo.com.br Conflito de interesses: Os autores declaram não haver nenhum interesse profissional ou pessoal que possa gerar conflito de interesses em relação a este manuscrito.

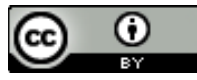

\section{Resumo}

As conquistas sociais dos brasileiros, dentre elas o Sistema Único de Saúde - SUS que expressa o nosso sistema de proteção social, ocorreu tardiamente. Trata-se de entender que seu desenvolvimento se dá em um contexto histórico de demolição dos direitos e redução da participação do Estado, diante de uma política neoliberal em curso. Nessa conjuntura, havia a defesa que com a globalização econômica o Estado necessitava ser diferente e pregava sua baixa efetividade na promoção do desenvolvimento, ou seja, o papel central do Estado não seria de alavancar o desenvolvimento social e econômico, mas sim de ser um catalisador e facilitador desse desenvolvimento. Esses dois projetos contraditórios têm grandes repercussões no que diz respeito a políticas sociais, sendo que o projeto de reforma sanitária tem como uma de suas estratégias o SUS e como diretriz a democratização do acesso, a universalidade das ações, descentralização e a melhoria dos serviços assegurando a saúde como direito de todos e dever do Estado. Em relação ao projeto privatista pautado na redução da participação do Estado, defende-se e funciona pela logística do sistema capitalista e obviamente busca-se lucrar com os contratos firmados e articular a saúde pública aos interesses do mercado, havendo um ataque ao caráter público do SUS. O SUS sofre um processo de desmonte e sucateamento diante dos modelos e projetos neoliberais e seu intenso processo de privatização através das Organizações Sociais, parcerias e dos processos de precarização do trabalho. A própria ideia de parceria público-privada cria facilidades para entrada do capital privado, compromete a própria essência do serviço público, favorece um tipo de política pública que não será mais universal e sim focal e finalmente representa a mercantilização dos serviços públicos viabilizando os interesses do capital financeiro. A expansão público/privada e terceirizações ganharam forças com a Lei de Responsabilidade Fiscal - LRF de 2000, no qual seu princípio maior define que os entes públicos devem gastar menos que arrecadam, determinando vários limites ao poder executivo, dentre eles, a despesa com pessoal, limitando não ultrapassar $54 \%$ da receita corrente líquida do município, e se considerarmos que saúde tem muitas despesas com pessoal, a solução encontrada pelos administradores foi a parceria público-privada para não sofrerem as sanções da LRF. Além disso, verifica-se a permissão do Estado à apropriação do fundo público pelo capital, e dentro do contexto contemporâneo, sob o domínio do capital financeiro, assistimos a concessão de incentivos à iniciativa privada, como 
o aumento das renúncias fiscais, decorrentes da dedução dos gastos com planos de saúde no imposto de renda e das concessões fiscais às entidades privadas sem fins lucrativos, enfraquecendo a capacidade de arrecadação do Estado e prejudicando o financiamento do SUS.

Descritores: Parcerias Público-Privadas; Serviços Terceirizados; Privatização; Mercantilização; Organização Social. 